\title{
The Lactococcus lactis triosephosphate isomerase gene, tpi, is monocistronic
}

\author{
Michael R. Cancilla, ${ }^{1}$ Barrie E. Davidson, ${ }^{1}$ Alan J. Hillier, ${ }^{2}$ Nga Y. Nguyen ${ }^{3}$ \\ and John Thompson ${ }^{4}$
}

\begin{abstract}
Author for correspondence: Barrie E. Davidson. Tel: +613344 5912. Fax: +6133477730.
e-mail: davidson@biochemistry.unimelb.edu.au
\end{abstract}

1 Russell Grimwade School of Biochemistry, University of Melbourne, Parkville, Victoria 3052, Australia

2 Commonwealth Scientific and Industrial Research Organization, Division of Food Science and Technology, Dairy Research Laboratory, Highett, Victoria 3190 , Australia

3 Division of Cytokine Biology, Center for Biologics Evaluation and Research, Food and Drug Administration, Bethesda MD 20892, USA

4 Laboratory of Microbial Ecology, National Institute of Dental Research, Bethesda, MD 20892, USA
Triosephosphate isomerase (EC 5.3.1.1) from Lactococcus lactis was purified to electrophoretic homogeneity. Approximately $3 \mathrm{mg}$ purified enzyme (specific activity $3300 \mathrm{U} \mathrm{mg}^{-1}$ ) was obtained from $70 \mathrm{~g}$ (wet wt) cells. In solution, triosephosphate isomerase (pl 4.0-4.4) was observed to exist as a homodimer $\left(M_{r} 57000\right)$ of noncovalently linked subunits. The sequence of the first 37 amino acid residues from the $\mathrm{NH}_{2}$-terminus were determined by step-wise Edman degradation. This sequence, and that of a region conserved in all known bacterial triosephosphate isomerases, was used to design oligonucleotide primers for the synthesis of a lactococcal tpi probe by PCR. The probe was used to isolate a molecular clone of tpi from a גGEM11 library of $L$. lactis LM0230 DNA. The nucleotide sequence of tpi predicted a protein of 252 amino acids with the same $\mathrm{NH}_{2}$-terminal sequence as that determined for the purified enzyme and a subunit $\boldsymbol{M}_{\mathbf{r}}$ of $\mathbf{2 6 8 0 2}$ after removal of the $\mathrm{NH}_{2}$-terminal methionine. Escherichia coli cells harbouring a plasmid containing tpi had 15fold higher triosephosphate isomerase activity than isogenic plasmid-free cells, confirming the identity of the cloned gene. Northern analysis of $L$. lactis LM0230 RNA showed that a 900 base transcript hybridized with tpi. The 5' end of the transcript was determined by primer extension analysis to be a $G$ located 64 bp upstream from the tpi start codon. These transcript analyses indicated that in L. lactis, tpi is expressed on a monocistronic transcript. Nucleotide sequencing indicated that the DNA adjacent to tpi did not encode another Embden-Meyerhoff-Parnas pathway enzyme. The location of tpi on the $L$. lactis DL11 chromosome map was determined to be between map coordinates 1.818 and 1.978 .

Keywords: Lactococcus lactis, triosephosphate isomerase, transcript analysis, biased codon usage, enzyme purification

\section{INTRODUCTION}

The Gram-positive bacterium Lactococcus lactis plays an essential role in the manufacture of fermented milk products, such as cheese. The fermentation process requires the uptake of lactose as lactose 6-phosphate by the phosphoenolpyruvate: lactose phosphotransferase system, and the subsequent hydrolysis of lactose 6-phosphate into glucose and galactose 6-phosphate by 6 -phospho- $\beta$ -

Abbreviations: EMP, Embden-Meyerhoff-Parnas; PTH, phenylthiohydantoin.

The GenBank accession number for the nucleotide sequence reported in this paper is 007640 .
D-galactosidase (EC 3.2.1.85). Both products are converted into lactic acid via the Embden-Meyerhoff-Parnas (EMP) pathway: glucose directly and galactose 6-phosphate via dihydroxyacetone phosphate and glyceraldehyde 3-phosphate, products of the tagatose 6-phosphate pathway. Lactose catabolism to lactic acid provides most of the energy needs of this bacterium. The reaction catalysed by triosephosphate isomerase (EC 5.3.1.1), namely the interconversion of dihydroxyacetone phosphate and glyceraldehyde 3-phosphate, is the first common step for the catabolism of the monosaccharide moieties of lactose.

The plasmid-borne genes encoding enzymes responsible for the uptake, phosphorylation and hydrolysis of lactose, 
and conversion of galactose 6-phosphate into triosephosphates have been cloned and characterized (Crow et al., 1983; de Vos et al., 1990; van Rooijen \& de Vos, 1990; van Rooijen et al., 1991, 1992). The genes required for the uptake and catabolism of glucose into lactic acid are chromosomally encoded, since plasmid-cured strains of L. lactis can utilize glucose as the sole carbon source (Efstathiou \& McKay, 1977). We recently discovered that the $L$. lactis genes encoding phosphofructokinase (EC 2.7.1.11), pyruvate kinase (EC 2.7.1.40), and lactate dehydrogenase (EC 1.1.1.27) are organized in a single tricistronic transcriptional unit, the las operon (Llanos et al., 1993). This observation is of particular interest since these enzymes are closely regulated at the metabolic level and their relative activities have a major effect on the rates of energy production and lactic acid synthesis in lactic acid bacteria. An operon of this composition has not been reported for any other bacterium and its discovery raises questions about the organization of genes encoding other glycolytic enzymes in $L$. lactis.

Triosephosphate isomerase is one of the most abundant enzymes in bacterial cells (Noltmann, 1972) and has been described as the near-perfect catalyst (Knowles, 1991). In the eubacteria Escherichia coli, Corynebacterium glutamicum and Bacillus megaterium the gene ( $t p i)$ encoding the enzyme is located in a cluster of two or more genes encoding glycolytic enzymes (Pichersky et al., 1984; Eikmanns, 1992; Schläpfer \& Zuber, 1992). Northern analyses have revealed that this cluster constitutes a polycistronic operon in C. glutamicum (Schwinde et al., 1993).

In view of the role of triosephosphate isomerase in the homofermentative process in L. lactis, we have carried out an analysis of this enzyme and its structural gene. In this report we describe the purification of triosephosphate isomerase from $L$. lactis to electrophoretic homogeneity, its $\mathrm{NH}_{2}$-terminal amino acid sequence and some properties of the purified enzyme. The availability of the sequence enabled us to clone the gene encoding triosephosphate isomerase, which we have designated tpi, and to analyse its structure and transcriptional organization.

\section{METHODS}

Bacterial strains, plasmids, bacteriophage, and culture conditions. The bacterial strains, plasmids, and bacteriophage used in this study are listed in Table 1. L. lactis strains LM0230 and DL11 were grown at $30^{\circ} \mathrm{C}$ in M17G [M17 medium (Terzaghi \& Sandine, 1975), without lactose but supplemented with $0.5 \%$ $(\mathrm{w} / \mathrm{v})$ glucose]. L. lactis K1-42 was grown for purification of triosephosphate isomerase in a previously described medium (Thompson \& Saier, 1981). D-Ribose $(0.5 \%, \mathrm{w} / \mathrm{v})$ was used as the carbon source so that the cell extract could also be used to purify fructokinase II, which is derepressed by ribose (Thompson et al., 1991b); triosephosphate isomerase levels are not altered by growth in D-ribose. After overnight growth at $32{ }^{\circ} \mathrm{C}$ to stationary phase, the cells were harvested by centrifugation, washed by resuspension and centrifugation from KP buffer (KP buffer is $10 \mathrm{mM}$ potassium phosphate, $\mathrm{pH} 7 \cdot 0$ ), and stored at $-20^{\circ} \mathrm{C}$ until required. The cell yield was approxi- mately $3.5 \mathrm{~g}$ (wet wt) of cells per litre. E. coli was grown in $2 \mathrm{YT}$ medium (Miller, 1972) at $37{ }^{\circ} \mathrm{C}$ with aeration. Antibiotics were used at the following concentrations: erythromycin, 200$400 \mu \mathrm{g} \mathrm{ml}^{-1}$; ampicillin, $100 \mu \mathrm{g} \mathrm{ml}^{-1}$; kanamycin, $25 \mu \mathrm{g} \mathrm{ml}^{-1}$; and tetracycline, $12.5 \mu \mathrm{g} \mathrm{ml}^{-1}$.

Chemicals and reagents. Protein standards for SDS-PAGE and gel filtration chromatography, isoelectric focusing standards, Ampholine polyacrylamide gel plates, DEAE-Sephacel and phenyl-Sepharose CL-4B were obtained from Pharmacia. Ultrogel AcA 44 was purchased from Sepracor and hydroxylapatite (Fast Flow) from Calbiochem. DL-Glyceraldehyde 3phosphate diethyl acetal (monobarium salt), $\alpha$-glycerophosphate dehydrogenase (type III, rabbit muscle), and other reagents, were purchased from Sigma.

\section{Purification of triosephosphate isomerase}

The SDS-PAGE procedure of Laemmli (1970) was used to monitor enzyme purity throughout the purification. Preparation of SDS-polyacrylamide gels, electrophoresis conditions, and staining procedures have been described previously (Thompson, 1989). Protein concentrations were determined by use of the Bio-Rad protein dye-binding reagent with BSA as the standard. Except where indicated, all purification steps were carried out at $4^{\circ} \mathrm{C}$.

(i) Cell disruption and preparation of high-speed supernatant. Frozen cells of $L$. lactis K1-42 (70 g wet wt) were thawed and resuspended in $\mathrm{KP}$ buffer to a volume of $150 \mathrm{ml}$. The cells were disrupted at $0{ }^{\circ} \mathrm{C}$ by three 5 min periods of sonic oscillation with a Branson model 350 sonifier operating at $75 \%$ maximum power. Intact cells and debris were removed by centrifugation $(25000 \mathrm{~g}, 30 \mathrm{~min})$, and the supernatant was dialysed overnight against $41 \mathrm{KP}$ buffer. The dialysate was concentrated twofold by ultrafiltration through a Diaflo PM-10 membrane (Amicon) and centrifuged $(180000 \mathrm{~g}, 2 \mathrm{~h})$.

(ii) Phosphocellulose chromatography. The high-speed supernatant $(54 \mathrm{ml})$ was transferred to a $2.6 \times 24 \mathrm{~cm}$ column of phosphocellulose (Whatman P-11) previously equilibrated with KP buffer. The non-adsorbed proteins, which included triosephosphate isomerase, were eluted with KP buffer. The active fractions were pooled and concentrated to $20 \mathrm{ml}$ by ultrafiltration.

(iii) DEAE-Sephacel chromatography. The concentrate from step (ii) was transferred to a $2.6 \times 24 \mathrm{~cm}$ column of DEAE-Sephacel previously equilibrated with $25 \mathrm{mM}$ HEPES, $\mathrm{pH} 7 \cdot 5$. After washing the column with $150 \mathrm{ml}$ of this buffer, a $600 \mathrm{ml}$ linear $\mathrm{NaCl}$ gradient $(0 \cdot 2-0.5 \mathrm{M})$ in $25 \mathrm{mM}$ HEPES, $\mathrm{pH} 7 \cdot 5$, was passed through the column and $5 \mathrm{ml}$ fractions were collected. The active fractions (usually fractions 45-51) were pooled and concentrated to $10 \mathrm{ml}$ by ultrafiltration.

(iv) Phenyl-Sepharose chromatography. Solid $\mathrm{NaCl}$ was added to the concentrate from step (iii) to a final concentration of $1 \mathrm{M}$. The sample was then applied to a $1 \times 28 \mathrm{~cm}$ column of phenylSepharose CL-4B equilibrated with KP buffer containing $1 \mathrm{M}$ $\mathrm{NaCl}$. Unadsorbed proteins were eluted with this buffer, then a $300 \mathrm{ml}$ linear decreasing gradient of $\mathrm{NaCl}(0 \cdot 6-0 \cdot 1 \mathrm{M})$ in $\mathrm{KP}$ buffer was applied to the column and $2 \mathrm{ml}$ fractions were collected. The active fractions (fractions 10-24) were pooled and concentrated to $3 \mathrm{ml}$ by ultrafiltration.

(v) Hydroxylapatite chromatography. The concentrate from step (iv) was desalted and exchanged for KP buffer by passage through a PD-10 gel filtration column previously equilibrated with KP buffer. The desalted preparation was transferred to a $1 \times 5 \mathrm{~cm}$ column of hydroxylapatite equilibrated with $\mathrm{KP}$ buffer. In contrast to the contaminating proteins, the triosephosphate 
Table 1. Bacterial strains, plasmids and bacteriophage used

\begin{tabular}{|c|c|c|}
\hline & Characteristics & Source/reference \\
\hline \multicolumn{3}{|l|}{ Strains } \\
\hline \multicolumn{3}{|l|}{ L. lactis } \\
\hline $\mathrm{K} 1-42$ & $\begin{array}{l}\text { L. lactis subsp. lactis } \mathrm{K} 1 \text { after spontaneous loss of lac } \\
\text { plasmid and } \operatorname{Tn} 5306\end{array}$ & $\begin{array}{l}\text { Donkersloot \& Thompson } \\
\text { (1990); Thompson et al. } \\
\text { (1991a) }\end{array}$ \\
\hline LM0230 & $\begin{array}{l}\text { Plasmid-cured derivative of } L \text {. lactis subsp. cremoris C2 } \\
\text { (formerly } L \text {. lactis subsp. lactis } \mathrm{C} 2 \text { ) }\end{array}$ & $\begin{array}{l}\text { Efstathiou \& McKay } \\
\text { (1977); Salama et al. } \\
\text { (1991) }\end{array}$ \\
\hline DL11 & $\mathrm{Prt}^{-}$derivative of $L$. lactis subsp. lactis ATCC 11454 & Tulloch et al. (1991) \\
\hline \multicolumn{3}{|c|}{ ( } \\
\hline JM107 & $\begin{array}{l}\text { end } A 1 \text { gyr } A 96 \text { thi-1 bsdR } 17 \text { supE44 rel } A 1 \Delta(\text { lac-pro } A B) \\
\left(\mathrm{F}^{\prime} \text { traD36 pro } A B \text { lac } \mathrm{I}^{\mathrm{q}} Z \Delta \mathrm{M} 15\right)\end{array}$ & $\begin{array}{l}\text { Yanisch-Perron et al. } \\
\text { (1985) }\end{array}$ \\
\hline SURE & $\begin{array}{l}\mathrm{e} 14^{-}(m c r A) \Delta(m c r C B-b s d S M R-m r r) 171 \text { sbcC recB rec } \\
\text { umu } C:: \operatorname{Tn} 5\left(\mathrm{Km}^{\mathrm{r}}\right) \text { wrrC supE44 lac gyrA96 relA1 thi-1 } \\
\text { end } A 1\left[\mathrm{~F}^{\prime} \text { pro } A B \text { lac } \mathrm{I}^{\mathrm{q}} Z \Delta \mathrm{M} 15\right]\end{array}$ & Stratagene \\
\hline \multicolumn{3}{|l|}{ Plasmids } \\
\hline pGEM-T & $\mathrm{Ap}^{\mathrm{r}} \Delta \mathrm{lac} Z, 3005 \mathrm{bp}$ vector for cloning PCR products & Promega \\
\hline pJDC9 & $\mathrm{Em}^{\mathrm{r}} \Delta l a c Z, 6.85 \mathrm{kbp}$ cloning vector & Chen \& Morrison (1988) \\
\hline pMU5501 & $\begin{array}{l}\text { Ap }{ }^{\mathrm{r}} \text {, pGEM-T with } 503 \text { bp of } t p i \text { prepared by PCR } \\
\text { amplification of L. lactis LM0230 DNA }\end{array}$ & This study \\
\hline pMU5502 & $\begin{array}{l}\mathrm{Em}^{\mathrm{r}}, \mathrm{pJDC} 9 \text { with a } 6.0 \mathrm{kbp} \text { EcoRI fragment } \\
\text { containing tpi from L. lactis LM0230 }\end{array}$ & This study \\
\hline pMU5503 & $\begin{array}{l}\mathrm{Em}^{\mathrm{r}} \text {, pJDC9 with a } 2.0 \mathrm{kbp} \text { DraI fragment containing } \\
\text { tpi from L. lactis LM } 0230\end{array}$ & This study \\
\hline \multicolumn{3}{|c|}{ Bacteriophage } \\
\hline$\lambda 268$ & $\begin{array}{l}\lambda \text { GEM11 with a } 21.0 \mathrm{kbp} \text { partial Sau3AI fragment } \\
\text { from } L \text {. lactis LM0230 in the XboII site }\end{array}$ & This study \\
\hline
\end{tabular}

isomerase was not adsorbed by this matrix, and the purified enzyme (about $3 \mathrm{mg}$ ) was eluted in the wash fractions and concentrated by ultrafiltration.

$\boldsymbol{M}_{\mathrm{r}}$ determinations. The $M_{\mathrm{r}}$ of native triosephosphate isomerase in solution was determined by the gel filtration method of Andrews (1964) using a $1.6 \times 94 \mathrm{~cm}$ column of Ultrogel AcA44 equilibrated with $50 \mathrm{mM}$ potassium phosphate buffer, $\mathrm{pH} 7$, containing $0 \cdot 1 \mathrm{M} \mathrm{NaCl}$. Standard proteins used to calibrate the column were: BSA $\left(M_{\mathrm{r}} 66000\right)$, ovalbumin (45000), carbonic anhydrase (31000) and chymotrypsinogen A (25000). SDSPAGE was used to estimate the subunit $M_{\mathrm{r}}$ of the denatured triosephosphate isomerase. Standard proteins used to calibrate the gel were: phosphorylase $b(97000)$; BSA, ovalbumin, carbonic anhydrase, soybean trypsin inhibitor (21500) and lysozyme (14400).

Isoelectric focusing and pl estimation. The isoelectric point (pI) of purified triosephosphate isomerase was determined by analytical isoelectric focusing in a Multiphor model 2117 flatbed electrophoresis unit (Pharmacia). Electrophoresis conditions, and procedures for fixing, staining and destaining of $1 \mathrm{~mm}$ thick isoelectric focusing gels were done according to the manufacturer's instructions. The pI calibration standards (pI range 3-10) and precast Ampholine polyacrylamide gel plates ( $\mathrm{pH}$ range 3.5-9.5) were purchased from Pharmacia.

Triosephosphate isomerase assay. Triosephosphate isomerase catalyses the reversible conversion of D-glyceraldehyde 3phosphate to dihydroxyacetone phosphate. Enzyme activity was determined spectrophotometrically at $340 \mathrm{~nm}$ by moni- toring the rate of NADH-dependent, $\alpha$-glycerophosphatedehydrogenase-mediated conversion of dihydroxyacetone phosphate (produced from glyceraldehyde 3-phosphate) to $\alpha$ glycerophosphate. This assay would be perturbed by glyceraldehyde-3-phosphate dehydrogenase and NADH oxidase activities in the sample; however, the relative levels of these enzymes in the high-speed supernatant compared with that of triosephosphate isomerase were negligible. One unit of triosephosphate isomerase was defined as the amount of enzyme that catalysed the oxidation of $1 \mu \mathrm{mol} \mathrm{NADH}$ (i.e. equivalent to the conversion of $1 \mu \mathrm{mol}$ glyceraldehyde 3-phosphate to dihydroxyacetone phosphate) per min at $22^{\circ} \mathrm{C}$. The standard $1 \mathrm{ml}$ assay mixture contained $0 \cdot 1 \mathrm{M}$ imidazole/ $\mathrm{HCl}$ buffer $(\mathrm{pH} 7 \cdot 0)$, $0.1 \mathrm{mM} \mathrm{NADH}, 10 \mathrm{mM} \mathrm{MgCl}_{2}, 0.25 \mathrm{mM}$ D-glyceraldehyde 3phosphate, $5 \mathrm{U} \alpha$-glycerophosphate dehydrogenase (EC 1.1.1.8) and triosephosphate isomerase.

$\mathbf{N H}_{\mathbf{2}}$-terminal amino acid sequence. Approximately $100 \mathrm{pmol}$ dry, salt-free protein was dissolved in $30 \mu \mathrm{l}$ sequencing-grade trifluoroacetic acid $(0 \cdot 1 \%, v / v)$, and dried on a glass fibre filter membrane which had been coated with polybrene. The protein was subjected to three filter cycles with an Applied Biosystems model $470 \mathrm{~A}$ gas phase microsequencer, and PTH-amino acid derivatives were identified on an Applied Biosystems model $120 \mathrm{~A}$ analyser.

DNA techniques and sequence analysis. E. coli cells were transformed by the method of Hanahan (1983). Plasmid DNA from E. coli was isolated by alkaline-lysis procedure (Birnboim \& Doly, 1979) and was purified by the addition of PEG (to 
$6.5 \%, \mathrm{v} / \mathrm{v}$ ) and $\mathrm{NaCl}$ (to a final concentration of $0.4 \mathrm{M}$ ) at $4{ }^{\circ} \mathrm{C}$, followed by centrifugation $\left(12000 \mathrm{~g}, 15 \mathrm{~min}, 4^{\circ} \mathrm{C}\right)$. Genomic DNA used as template in the PCR was isolated from $L$. lactis LM0230 as described previously (Cancilla et al., 1992). Oligonucleotides were synthesized in an Applied Biosystems model 381A DNA synthesizer. Bacteriophage $\lambda$ was isolated from plate lysates and $\lambda$ DNA was purified on Qiagen minicolumns according to the manufacturer's instructions. Digestions, electrophoresis, transfers, hybridizations, and other DNA manipulations were performed as described elsewhere (Sambrook et al., 1989; Tanskanen et al., 1990; Tulloch et al., 1991). DNA sequence determinations were carried out on both DNA strands using an Applied Biosystems model 373A automated DNA sequencer (Llanos et al., 1992). DNA and amino acid sequences were analysed using the ANGIs suite of programs on the University of Sydney SUN computer system. The suite includes the Staden (Staden, 1978) and University of Wisconsin Genetics Computer Group programs.

Construction of a molecular probe for tpi. The following oligonucleotides were used as polymerase chain reaction (PCR) primers: N-TPI, 5'-GG(ACGT)AA(CT)TGGAA(AG)ATGAA-3', and C-TPI, 5'-CC(ACGT)GT(ACGT)CC(AGT)AT(ACGT)GCCCA-3'. N-TPI encoded amino acid residues 8-13 (GNWKMN) of L. lactis K1-42 triosephosphate isomerase, and the complementary strand of C-TPI encoded WAIGTG, a conserved sequence in all known bacterial triosephosphate isomerases near residues $171-176$. The PCR mix ( $50 \mu \mathrm{l}$ final volume) consisted of template DNA (10-20 ng), N-TPI and CTPI (250 ng each), deoxynucleoside triphosphates $(200 \mu \mathrm{M}$ each), $1 \times$ Taq DNA polymerase buffer (Boehringer Mannheim), and 2 U Taq DNA polymerase (Boehringer Mannheim). The reaction was carried out in a thermal sequencer (model FTS-1C, Corbett Research) as follows: $95^{\circ} \mathrm{C}$ for $3 \mathrm{~min}$, and then 30 cycles of $45^{\circ} \mathrm{C}$ for $1 \mathrm{~min}, 72^{\circ} \mathrm{C}$ for $1.5 \mathrm{~min}$, and $95^{\circ} \mathrm{C}$ for $0.5 \mathrm{~min}$. The amplified product was isolated and cloned into pGEM-T.

Northern analysis. Total RNA was purified from L. lactis LM0230, electrophoresed, transferred to a nylon membrane and hybridized as described previously (Chandry et al., 1994). The size of the tpi transcript was determined by comparison of its electrophoretic mobility with those of a set of RNA markers of $0 \cdot 24-9 \cdot 5 \mathrm{~kb}(\mathrm{BRL})$

Primer extension analysis. Total RNA $(5 \mu \mathrm{g})$ was annealed with $750 \mathrm{ng}$ of the oligonucleotide tpi2 (5'-GCACCGATAACTGATTC- $3^{\prime}$ ) in $5 \mu \mathrm{l}$ water, by incubation at $90^{\circ} \mathrm{C}$ for $1 \mathrm{~min}$ then $42^{\circ} \mathrm{C}$ for $5 \mathrm{~min}$. Radiolabelled $\mathrm{cDNA}$ was synthesized by using $\left[{ }^{35} \mathrm{~S}\right] \mathrm{dATP} \alpha \mathrm{S}$ and AMV reverse transcriptase (Boehringer Mannheim), according to the method of Chandry et al. (1994). The products of the four different dideoxy sequencing reactions obtained with the fmol DNA sequencing system (Promega) using pMU5503 as the template and tpi 2 as the primer, served as the size standards on the $6 \%(\mathrm{w} / \mathrm{v})$ polyacrylamide $/ 7 \mathrm{M}$ urea gel.

\section{RESULTS}

\section{Purification and properties of triosephosphate isomerase}

Cell-free extracts of $L$. lactis K1-42 grown with ribose exhibited high levels of triosephosphate isomerase activity $\left(60 \mathrm{U} \mathrm{mg}^{-1}\right)$, and were a suitable starting material for purification of the enzyme (Table 2). The five-stage purification procedure usually provided $3-4 \mathrm{mg}$ of electrophoretically pure enzyme from $70 \mathrm{~g}$ (wet wt) $L$. lactis cells. The purified enzyme remained stable for several months when stored at $-20^{\circ} \mathrm{C}$ in $50 \mathrm{mM}$ potassium phosphate buffer ( $\mathrm{pH} 7 \cdot 0$ ), exhibiting little loss of activity upon repeated (at least four times) freezing and thawing. The $M_{r}$ of native triosephosphate isomerase was estimated to be 57000 by Ultrogel AcA44 filtration chromatography (data not shown), while SDS-PAGE of the fully reduced enzyme revealed a single polypeptide of $M_{\mathrm{r}} 27000$ (Fig. 1, lane 5). These data indicated that triosephosphate isomerase from $L$. lactis exists in the native state as a homodimer of noncovalently linked subunits. Although SDS-PAGE of purified triosephosphate isomerase revealed a single protein band, the same preparation was resolved into two species by analytical electrofocusing (data not shown). The pIs were estimated to be 4.0 for the more sharply focused polypeptide, and 4.4 for the more diffuse species. Whether this microheterogeneity reflected post-translational modification(s), deamidation or proteolysis during purification, or whether it was an artefact of the electrofocusing procedure, is unclear. Microsequencing of the pure triosephosphate isomerase provided a reasonably unambiguous sequence for the first $37 \mathrm{NH}_{2}$-terminal residues: Ser-Arg-Lys-Pro-Ile-Ile-Ala-Gly-Asn-(Trp/ Cys)-Lys - Met - Asn - Lys - Thr - Leu - (Ala/Ser) - Glu - Ala Gln-Ala-Phe-Val-Glu-Ala-Val-Lys-Asn-Asn-Leu-Pro(Pro/Ser)-Ser-Asp-Asn-Val-Glu.

\section{Molecular cloning and sequence analysis of tpi}

The availability of the $\mathrm{NH}_{2}$-terminal sequence of $L$. lactis triosephosphate isomerase enabled the use of PCR to generate a specific probe for the $L$. lactis gene (which we designated $t p i$ ) encoding the enzyme. One primer, N-TPI, was designed from the $\mathrm{NH}_{2}$-terminal sequence data and the other, C-TPI, was designed from the sequence WAIGTG, which is conserved in all known bacterial triosephosphate isomerase sequences. PCR amplification of $L$. lactis DNA with these primers yielded a fragment of $503 \mathrm{bp}$, which is the approximate size expected from known triosephosphate isomerase amino acid sequences. The fragment was cloned (pMU5501) (Table 1) and its nucleotide sequence was determined. The predicted amino acid sequence indicated that the fragment contained the expected region of $t p i$. The $503 \mathrm{bp}$ fragment from pMU5501 was then used as a specific probe to screen a גGEM11 genomic library of L. lactis LM0230 (Llanos et al., 1992). One clone ( 2268$)$ hybridized strongly with the probe. DNA was isolated from this clone and Southern analyses were used to construct a restriction map of a $6.0 \mathrm{kbp}$ EcoRI fragment located within the $2268 \mathrm{~L}$. lactis DNA insert (Fig. 2). The $6.0 \mathrm{kbp}$ EcoRI fragment that hybridized with the tpi probe was subcloned from $\lambda 268$ into $\mathrm{pJDC}$, yielding a recombinant plasmid containing $t p i$ and its flanking DNA (pMU5502).

HaeIII, DraI, HindIII, $S s p I$ and PvuII fragments from the $6.0 \mathrm{kbp}$ insertion in pMU5502 were cloned in pJDC9, and the nucleotide sequences of these fragments were determined. The 1138 bp nucleotide sequence shown in Fig. 
Table 2. Purification of triosephosphate isomerase from L. lactis K1-42

\begin{tabular}{|lccccc|}
\hline Purification step* & $\begin{array}{c}\text { Enzyme } \\
\text { activity } \\
\text { (U) }\end{array}$ & $\begin{array}{c}\text { Amount } \\
\text { of protein } \\
\text { (mg) }\end{array}$ & $\begin{array}{c}\text { Sp. act. } \\
\text { (U mg } \mathbf{~ m}^{-1} \text { ) }\end{array}$ & $\begin{array}{c}\text { Purification } \\
\text { (-fold) }\end{array}$ & $\begin{array}{c}\text { Yield } \\
\text { (\%) }\end{array}$ \\
\hline High-speed supernatant & 127000 & 2160 & 60 & 1 & 100 \\
Phosphocellulose P-11 chromatography & 84500 & 1460 & 60 & 1 & 67 \\
DEAE-Sephacel chromatography & 31100 & 220 & 140 & $2 \cdot 3$ & 25 \\
Phenyl-Sepharose chromatography & 28700 & $12 \cdot 3$ & 2300 & 38 & 23 \\
Hydroxylapatite chromatography & 11500 & $3 \cdot 5$ & 3300 & 55 & 9 \\
\hline
\end{tabular}

* See Methods for details.

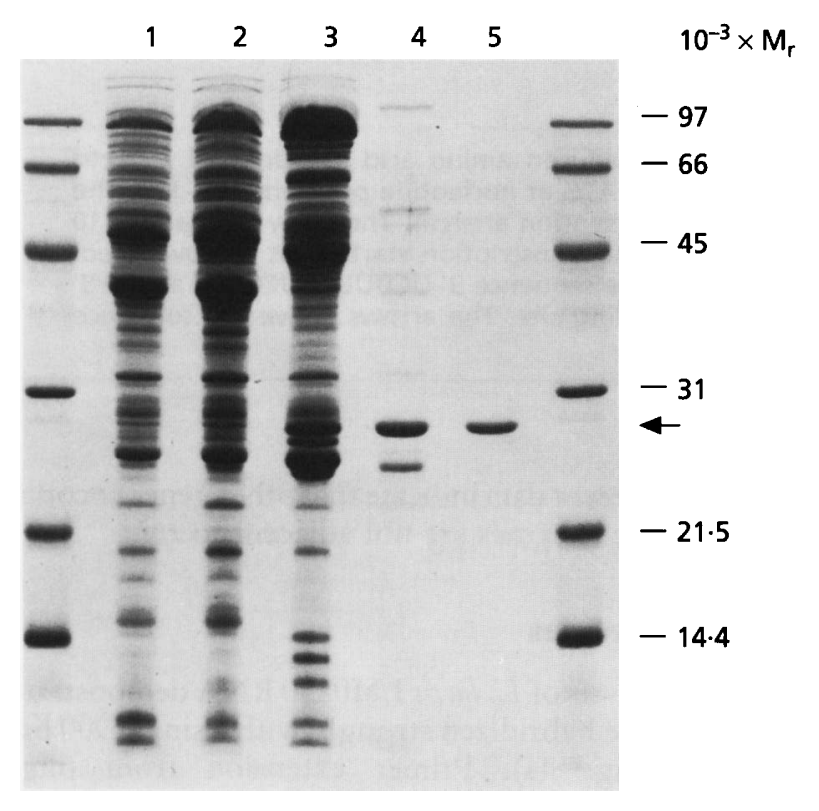

Fig. 1. Purification and $M_{r}$ determination of triosephosphate isomerase from $L$. lactis K1-42. SDS-PAGE $(12.5 \%$, w/v, acrylamide) of samples from each stage of triosephosphate isomerase purification: high-speed supernatant (lane 1); phosphocellulose (lane 2); DEAE-Sephacel (lane 3); phenylSepharose (lane 4); hydroxylapatite (lane 5). The numbers on the right are the molecular sizes of standard proteins (see Methods) electrophoresed in the right and left hand lanes. The arrow indicates the subunit of purified triosephosphate isomerase in lane $5\left(M_{r} 27000\right)$.

3 includes the region that hybridized with the tpi probe and contains an ORF of 253 codons. Using the first ATG in the ORF as the translation-initiation codon, the deduced amino acid sequence at the $\mathrm{NH}_{2}$-terminus of the ORF was identical to the $\mathrm{NH}_{2}$-terminal sequence we had determined for triosephosphate isomerase from $L$. lactis K1-42. This observation provided strong evidence that the ORF is tpi. The nucleotide sequence predicted a chain length of 252 amino acids and a subunit $M_{\mathrm{r}}$ of 26802 for $L$. lactis triosephosphate isomerase, assuming the posttranslational removal of the $\mathrm{NH}_{2}$-terminal methionine, as observed in our protein sequence data. The predicted subunit $M_{\mathrm{r}}$ agreed with the observed subunit $M_{\mathrm{r}}$ of 27000

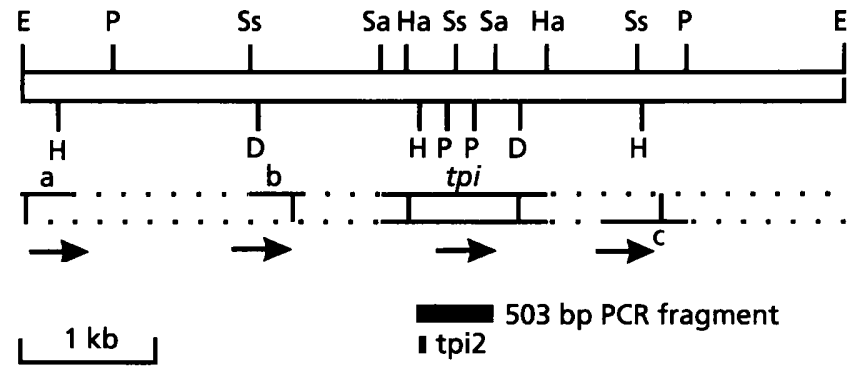

Fig. 2. Restriction map of the $6.0 \mathrm{kbp}$ EcoRI insert in pMU5502 containing $L$. lactis tpi. The digestion sites shown are for EcoRI (E), HindIII (H), Pvull (P), Sspl (Ss), Dral (D), Sau3Al (Sa), and Haelll $(\mathrm{Ha})$. The positions of tpi, ORFs $a, b$ and $c$ are indicated by rectangles, with arrows showing their orientations. Solid portions of the rectangles indicate sequenced regions. The locations of the tpi probe generated by PCR and the oligonucleotide tpi2 used in primer extension analysis are indicated.

for triosephosphate isomerase (Fig. 1). The $\mathrm{pI}$ of the protein predicted from the tpi sequence was $4 \cdot 4$, which is also in agreement with the values that were determined experimentally. A putative ribosome-binding site was identified $8 \mathrm{bp}$ upstream from the tpi initiation codon (Fig. 3). The $3^{\prime}$ flanking DNA of tpi contained an inverted-repeat sequence followed by TTT (Fig. 3). Transcripts of this region could form a stem-loop structure with a calculated free energy value (Tinoco $e t a l$., 1973) of $-15.6 \mathrm{kcal} \mathrm{mol}^{-1}\left(-65.3 \mathrm{~kJ} \mathrm{~mol}^{-1}\right)$. A stemloop structure followed by UUU is likely to be a rhoindependent transcription terminator (d'Aubenton Carafa et al., 1990), causing RNA polymerase to stop transcribing at bp 988 (Fig. 3).

\section{Expression of $L$. lactis tpi in E. coli}

The predicted amino acid sequence (Fig. 3) provided evidence that the lactococcal DNA in pMU5502 contained $t p i$. To establish this point, we looked for the expression of the $L$. lactis tpi gene in $E$. coli cells harbouring pMU5502. Cell extracts from E. coli SURE(pMU5502) 


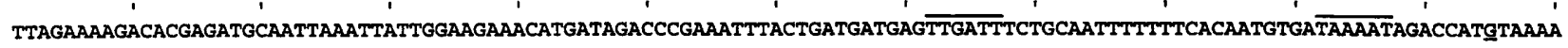

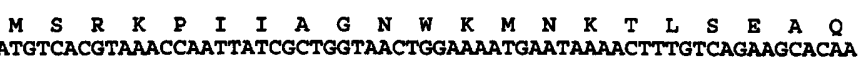

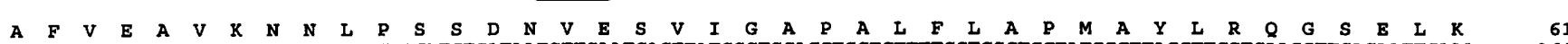
GCTTTTGTTGAAGCTGTTAAAAATAACTTGCCTTCATCTGATAATGTTGAATCAGTTATCGGTGCACCTGCTCTITTCCTCGCTCCTATGGCTTACCTTCGTCAAGGTTCAGAATTGAAA 360 $\underset{\text { CTTGCTGCTGAAAATAGCTACTTCGAAAATGCTGGAGCATTCACTGGTGAAAACAGCCCAGCTGCAATCGTTGACCTTGGTATTGAATACATCATCATCGGTCACAGCGAACGTCGTGAA }}{\mathbf{A}} \mathbf{A}$

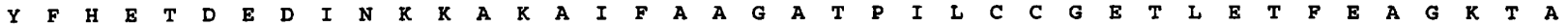
TATTTCCACGAAACTGACGAAGACATCAACAAAAAAGCAAAAGCAATCTTCGCTGCTGGAGCAACTCCAATCCTTTGTTGTGGTGAAACTTTGGAAACTTTTGAAGCTGGTAAAACAGCT

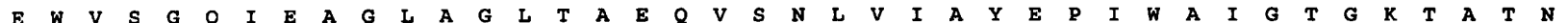
GAATGGGTTTCAGGTCAAATCGAAGCTGGTCTTGCAGGATTGACTGCTGAACAAGTTTCAAACTTAGTTATCGCTTACGAACCAATCTGGGCAATCGGAACTGGTAAAACTGCGACAAAC

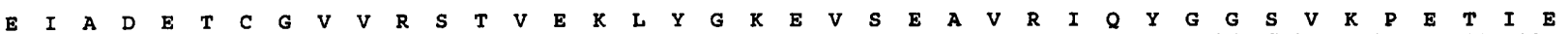
GAAATTGCTGACGAAACTTGTGGTGTTGTACGTTCAACAGTTGAAAAACTTTACGGAAAAGAATTTCAGAAGCTGTACGTATCCAATACGGTGGATCAGTAAAACCTGAAACAATCGAA

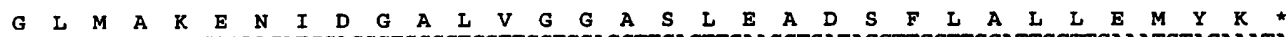
GGATTGATGGCTAAAGAAAACATCGACGGTGCCCTCGTTGGTGGAGCTTCACTTGAAGCTGATAGCTTCCTTGCATTGCTTGAAATGTACAAATAATTTTTAAATATGGGTTGAATGAAA

\begin{abstract}
Fig. 3. Nucleotide sequence of $L$. lactis tpi and its flanking DNA and the deduced amino acid sequence of $L$. lactis triosephosphate isomerase. The translated region of 253 codons starts with an ATG at nucleotide positions 178-180. The underlined $\mathrm{G}$ indicates the start point of transcription determined by primer extension analysis. The likely -35 and -10 hexanucleotides of the promoter (van de Guchte et al., 1992) upstream of the transcription start point are overlined. Double underlining indicates a sequence which exhibits complementarity to the sequence $3^{\prime}-U_{C U U U C C U C C A-5^{\prime}}$ at the $3^{\prime}$ end of $L$. lactis 165 rRNA (Ludwig et al., 1985) and is the likely ribosome-binding site. The arrows above the sequence indicate an inverted repeat that is a likely rho-independent terminator.
\end{abstract}

had a 15-fold higher level of triosephosphate isomerase activity $\left(81 \mathrm{U} \mathrm{mg}^{-1}\right)$ than those from plasmid-free E. coli SURE $\left(5 \cdot 3 \mathrm{U} \mathrm{mg}^{-1}\right)$. These data confirmed that pMU5502 contained $t p i$ and indicated that the gene was expressed in E. coli. By using the determined specific activity of pure $L$. lactis triosephosphate isomerase $\left(3300 \mathrm{U} \mathrm{mg}^{-1}\right.$; Table 2) the amount of $L$. lactis triosephosphate isomerase expressed in E. coli SURE(pMU5502) was calculated to be approximately $2 \%$ of the soluble cellular protein. SDSPAGE of the two extracts (data not shown) revealed an increased amount of a polypeptide of the expected size $\left(M_{\mathrm{r}} 27000\right)$ in E. coli SURE(pMU5502).

\section{Sequence analysis of the DNA adjacent to tpi}

Subcloning experiments from pMU5502 provided constructs which allowed the determination of partial nucleotide sequences of the DNA adjacent to $t p i$ (Fig. 2). Computer analysis of these sequences was used to identify potential ORFs. The predicted amino acid sequences of these ORFs (designated a, b and c, Fig. 2) were compared with the sequences in the GenPeptide data base using the FASTA program (Lipman \& Pearson, 1985). ORFs a and b shared $30 \%$ identity over a combined total of 145 amino acids with enzyme II encoded by $p t s G$ from Brevibacterium lactofermentum (C. glutamicum) (GenBank accession no. L18875), and ORF c shared $25 \%$ identity over 147 amino acids with the conjugated bile acid hydrolase encoded by cbb from Lactobacillus plantarum (GenBank accession no. M96175). Neither ORF exhibited any significant homology with known EMP pathway enzymes. Although additional nucleotide sequence and biochemical analyses need to be undertaken to establish the identity of ORFs a, $\mathrm{b}$ and $\mathrm{c}$, the present data indicate that other genes encoding EMP pathway enzymes are not adjacent to $t p i$.

\section{Transcript analyses}

Northern analysis of L. lactis LM0230 RNA demonstrated that a tpi probe hybridized strongly with a single 900 base transcript (Fig. 4a). Primer extension from oligonucleotide tpi2 using total RNA as template yielded one cDNA product (Fig. $4 \mathrm{~b}$ ). The mobility of the product was identical to that of the product in the $\mathrm{C}$ track, corresponding to bp 115 in Fig. 3. We concluded from this observation that the $G$ at bp 115 was the $5^{\prime}$ end of the tpi transcript; a transcript extending from this $5^{\prime}$ end to its $3^{\prime}$ end equivalent at bp 988 would be 873 bases long. This value agrees with the experimentally determined size of 900 bases for the tpitranscript, and indicates that L. lactis tpi is expressed as a monocistronic mRNA.

\section{Codon usage in L. lactis tpi}

Codon usage in $L$. lactis tpi exhibits a marked bias towards particular codons and away from others. Of the 61 possible amino acid codons, 24 are not used in this gene. While the low $\mathrm{G}+\mathrm{C}$ content $(37 \mathrm{~mol} \%)$ of $L$. lactis DNA may contribute to the non-usage of codons with a $\mathrm{G}$ or $\mathrm{C}$ in the third position, it cannot be the reason for the preference for $\mathrm{T}$ compared with $\mathrm{A}$ in the third position of Thr, Leu, Ile, Ala, Arg, and Gly codons. These data, when combined with compilations of codon usage for other genes encoding glycolytic enzymes (las operon) (Llanos et al., 1993) suggest that a strong bias exists in the codon usage of glycolytic genes in L. lactis. 
(a)

(b)

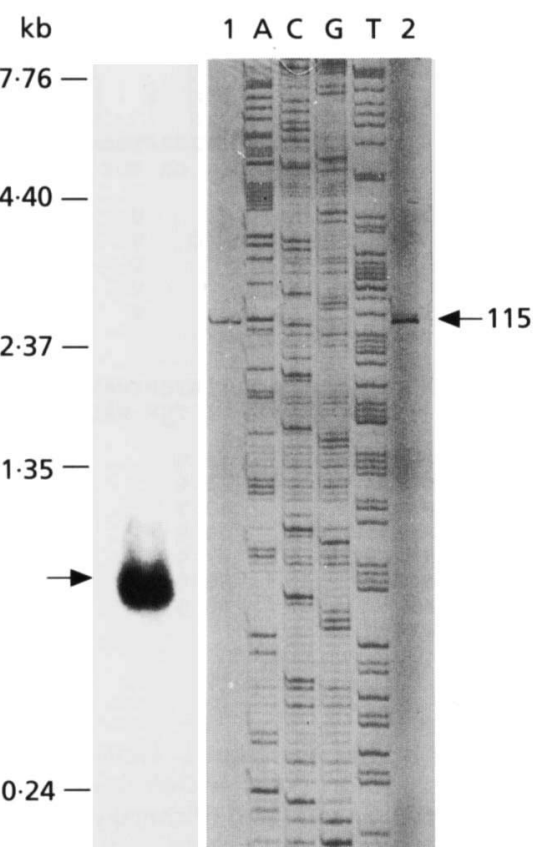

Fig. 4. Transcript analyses of $L$. lactis tpi. (a) Northern blot analysis of $L$. lactis LM0230 RNA. Total RNA from $L$. lactis LM0230 was electrophoresed, transferred to a nylon membrane, and hybridized with ${ }^{32}$ p-labelled 503 bp tpi probe. The numbers on the left indicate the sizes of RNA standards that migrated to the positions indicated. The arrow indicates the 900 base tpi transcript. (b) Primer extension analysis of the $5^{\prime}$ end of tpi. The autoradiograph shows electrophoretic separation of: lane 1, $10 \%$ of the primer extension reaction; and lane $2,20 \%$ of the primer extension reaction of CDNA products generated as described in Methods using oligonucleotide tpi2 as primer. Lanes $A, C, G$, and $T$, electrophoretic separation of the products of dideoxynucleotide sequencing using oligonucleotide tpi2 as primer and plasmid pMU5503 as a template. The number on the right corresponds to the nucleotide sequence numbering in Fig. 3 .

\section{Copy number and chromosomal location of tpi}

EcoRI, DraI, HaeIII, NruI, and SspI digests of L. lactis LM0230 chromosomal DNA were resolved by electrophoresis through agarose, and transferred to a nylon membrane. Hybridization of the membrane with a ${ }^{32} \mathrm{P}$ labelled tpi probe (data not shown) yielded the following hybridizing fragments: $6.0 \mathrm{kbp}$ (with EcoRI), $1.8 \mathrm{kbp}$ (DraI), $1.0 \mathrm{kbp}$ (HaeIII), > 10.0 kbp (NruI), and 1.5 and

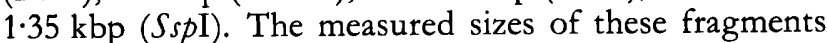
corresponded with the sizes predicted from restriction mapping (Fig. 2) and sequence data (Fig. 3). These observations indicated the presence of a single copy of $t p i$ in the L. lactis LM0230 chromosome.

A physical map of the L. lactis DL11 chromosome has been constructed by pulsed-field gel electrophoresis (Tulloch et al., 1991). To locate tpi on this map, samples of high- $M_{\mathrm{r}}$ DNA from $L$. lactis DL11 were digested with $S m a I$, NotI plus $S m a I$, and NotI, then separated by pulsedfield gel electrophoresis, and transferred to a nylon membrane. The membrane was probed with ${ }^{32} \mathrm{P}$-labelled tpi and fragments of 830,160 , and $160 \mathrm{kbp}$ were observed to hybridize (data not shown). The 830 and $160 \mathrm{kbp}$ bands corresponded to fragments $\mathrm{SmA}$ and $\mathrm{NtF}$, respectively (Tulloch et al., 1991). Since it has previously been shown that $\mathrm{NtF}$ is located within $\mathrm{SmA}$, we concluded that the single copy of tpi is located on the L. lactis DL11 chromosome within fragment $\mathrm{NtF}$, between coordinates 1.818 and 1.978 on the physical map (Tulloch et al., 1991).

\section{DISCUSSION}

The data reported above describe the enzymic and genetic characterization of triosephosphate isomerase from $L$. lactis. Electrophoretically homogeneous enzyme was purified from $L$. lactis and its $\mathrm{NH}_{2}$-terminal amino acid sequence was determined. PCR was then used to synthesize a specific lactococcal probe that could be used to isolate a molecular clone of $t p i$, the gene encoding triosephosphate isomerase. The $\mathrm{NH}_{2}$-terminal sequence of the purified enzyme was utilized to design one lowredundancy PCR primer while the sequence WAIGTG, which is conserved in all known triosephosphate isomerases (Fig. 5; Fothergill-Gilmore \& Michels, 1993), was used for the second.

Proof that our clone encoded triosephosphate isomerase was obtained by (i) the identity of its predicted $\mathrm{NH}_{2}$ terminal amino acid sequence with that determined for the purified enzyme, and (ii) the observation of elevated levels of triosephosphate isomerase activity in E. coli cells that contained the clone. The purified enzyme was shown to exist in solution as a homodimer $\left(M_{\mathrm{r}} 57000\right)$ of noncovalently linked subunits, and the sequence analysis of $t p i$ indicated that the enzyme subunits are identical and have an $M_{\mathrm{r}}$ of 26802 . The codon usage in L. lactis tpi was found to exhibit a strong bias. This was in direct agreement with the codon usage for genes of other $L$. lactis chromosomal genes encoding EMP pathway enzymes (Llanos et al., 1993), and noticeably different to data compiled from 67 other lactococcal genes (Chopin, 1993). By analogy with the situation in E. coli (Gouy \& Gautier, 1982) and yeast (Sharp et al., 1986), this observation suggests that $t p i$ is a strongly expressed gene.

The predicted amino acid sequence of $L$. lactis triosephosphate isomerase shares considerable identity with the amino acid sequences of other bacterial triosephosphate isomerases (Fig. 5). The identity ranges from $60 \%$ with the Bacillus megaterium enzyme down to $33 \%$ with the enzyme from Moraxella sp. Extensive structural and mutagenic studies with triosephosphate isomerase from various organisms have resulted in the identification of amino acid residues involved in subunit interaction, ligand binding and catalysis (Knowles, 1991; Lolis $e t$ al., 1990; Wierenga et al., 1992). Each subunit contains a catalytic centre that consists of a number of highly conserved amino acid residues (Wierenga et al., 1992). These conserved amino acids (Lys-12, His-96 and Glu168) were readily identified in the predicted sequence of triosephosphate isomerase from $L$. lactis (Fig. 5).

Northern blot analyses with $L$. lactis RNA showed that $t p i$ is expressed in a 900 base transcript. Given the length of 


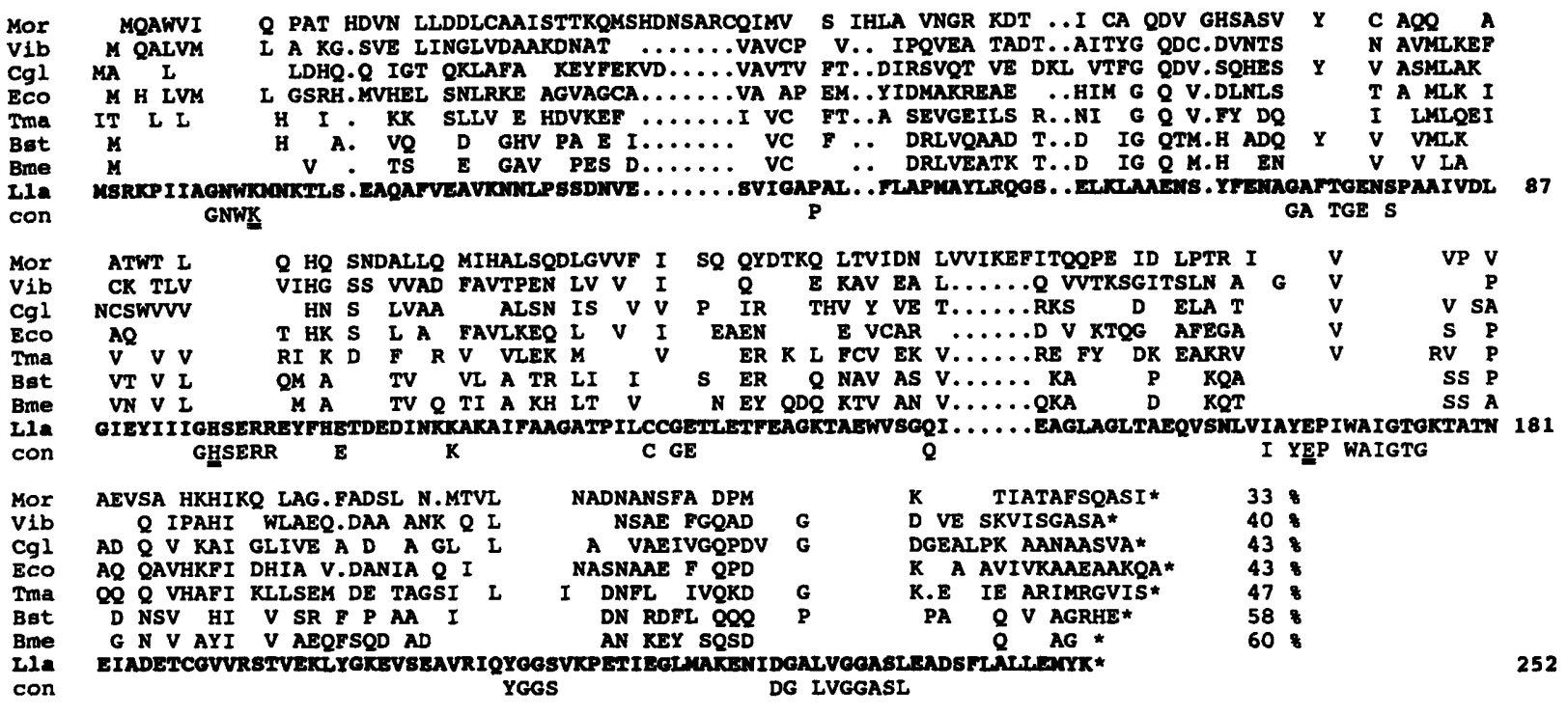

Fig. 5. Homology among the deduced amino acid sequences of triosephosphate isomerases from L. lactis LM0230 and other bacteria. The sequences are of triosephosphate isomerase from: Moraxella sp. (Mor) (Rentier-Delrue et al., 1993a), Vibrio sp. (Vib) (GenBank accession no. L27493), C. glutamicum (Cgl) (Eikmanns, 1992), E. coli (Eco) (Pichersky et al., 1984), Thermatoga maritima (Tma) (GenBank accession no. L27492), B. stearothermophilus (Bst) (Rentier-Delrue et al., $1993 \mathrm{~b}$ ), $B$. megaterium (Bme) (Schlapfer \& Zuber, 1992), L. lactis (Lla) (this study), and the conserved amino acids from the above (con). The first amino acid for each protein is the $\mathrm{NH}_{2}$-terminal amino acid. Spaces indicate positions where sequences are identical to that of $\mathrm{L}$. lactis; dots indicate gaps inserted to maximize the alignment; double underlining indicates catalytic residues in the triosephosphate isomerase active site (Wierenga et al., 1992); asterisks show the COOH-terminal extremity of each sequence; the percentages show the identity between each sequence and the $L$. lactis sequence.

the triosephosphate isomerase coding region (756 bp), and the distance between the start and termination sites of transcription ( $873 \mathrm{bp}$ ) we conclude that tpi is monocistronic. In a number of other bacterial species tpi has been found to be adjacent to genes encoding other enzymes of the EMP pathway. For example, in the Grampositive bacteria $C$. glutamicum and $B$. megaterium a gene cluster of gap (encoding glyceraldehyde-3-phosphate dehydrogenase, EC 1.2.1.12), pgk (encoding 3phosphoglycerate kinase, EC 2.7.2.3) and tpi has been discovered (Eikmanns, 1992; Schläpfer \& Zuber, 1992). The three enzymes encoded by the cluster catalyse sequential reactions in the pathway. Transcriptional analyses of the gap-pgk-tpi cluster from $C$. glutamicum identified tpi-containing transcripts corresponding to $g a p-p g k-t p i$ and $p g k-t p i$ (Schwinde $e t a l ., 1993)$. In E. coli, tpi is near $p f k$ (Shimosaka et al., 1982), the gene encoding phosphofructokinase, another enzyme involved in sugar metabolism. However, nucleotide sequence analysis has revealed that they have opposite orientations and must therefore be transcribed convergently from different promoters (Hellinga \& Evans, 1985). No experimental data have been reported on the size or composition of the $E$. coli tpi transcriptional unit or the identity of the upstream gene. Analysis of the nucleotide sequence of the DNA adjacent to tpi in L. lactis (Fig. 2) indicates that neither $p g k, g a p$, $p f k$ nor any other gene encoding an EMP pathway enzyme is present. Thus, the clustering (and possible cotranscription) of tpi and other genes encoding EMP pathway enzymes found in some Gram-positive bacteria and E. coli does not occur in L. lactis. Curiously,
L. lactis contains a different grouping of other genes for this pathway: an operon containing $p f k$, pyk and $l d b$ (Llanos et al., 1993). There seems therefore to be some diversity among prokaryotes in the arrangement of their EMP pathway genes. The possible reasons for this evident diversity are not apparent.

\section{ACKNOWLEDGEMENTS}

We are grateful to Sean Moore for assistance with gel preparation and use of the automated DNA sequencer. This study was supported by the Australian Research Council and the Australian Dairy Research and Development Corporation. M.R.C. acknowledges receipt of an Australian Dairy Research and Development Corporation Postgraduate Studentship.

\section{REFERENCES}

Andrews, P. (1964). Estimation of the molecular weights of proteins by Sephadex gel-filtration. Biochem J 91, 222-233.

d'Aubenton Carafa, Y., Brody, E. \& Thermes, C. (1990). Prediction of rho-independent Escherichia coli transcription terminators. A statistical analysis of their RNA stem-loop structures. $J$ Mol Biol 216, 835-858.

Birnboim, H. C. \& Doly, J. (1979). A rapid alkaline extraction procedure for screening recombinant plasmid DNA. Nucleic Acids Res 7, 1513-1523.

Cancilla, M. R., Powell, I. B., Hillier, A. J. \& Davidson, B. E. (1992). Rapid genomic fingerprinting of Lactococcus lactis strains by arbitrarily primed polymerase chain reaction with ${ }^{32} \mathrm{P}$ and fluorescent labels. Appl Environ Microbiol 58, 1772-1775. 
Chandry, P. S., Davidson, B. E. \& Hillier, A. J. (1994). Temporal transcription map of the Lactococcus lactis bacteriophage sk1. Microbiology 140, 2251-2261.

Chen, J.-D. \& Morrison, D. A. (1988). Construction and properties of a new insertion vector, pJDC9, that is protected by transcriptional terminators and useful for cloning of DNA from Streptococcus pneumoniae. Gene 64, 155-164.

Chopin, A. (1993). Organization and regulation of genes for amino acid biosynthesis in lactic acid bacteria. FEMS Microbiol Rev 12, 21-38.

Crow, V. L., Davey, G. P., Pearce, L. E. \& Thomas, T. D. (1983). Plasmid linkage of the D-tagatose-6-phosphate pathway in Streptococcus lactis: effect on lactose and galactose metabolism. $J$ Bacteriol 153, 76-83.

Donkersloot, J. A. \& Thompson, J. (1990). Simultaneous loss of $N^{5}$-(carboxyethyl) ornithine synthase, nisin production, and sucrose-fermenting ability by Lactococcus lactis K1. J Bacteriol 172, $4122-4126$.

Efstathiou, J. D. \& McKay, L. L. (1977). Inorganic salts resistance associated with a lactose-fermenting plasmid in Streptococcus lactis. J Bacteriol 130, 257-265.

Eikmanns, B. J. (1992). Identification, sequence analysis, and expression of a Corynebacterium glutamicum gene cluster encoding three glycolytic enzymes, glyceraldehyde-3-phosphate dehydrogenase, 3-phosphoglycerate kinase, and triosephosphate isomerase. J Bacteriol 174, 6076-6086.

Fothergill-Gilmore, L. A. \& Michels, P. A. M. (1993). Evolution of glycolysis. Prog Biophys Mol Biol 59, 105-235.

Gouy, M. \& Gautier, C. (1982). Codon usage in bacteria : correlation with gene expressivity. Nucleic Acids Res 10, 7055-7074.

van de Guchte, M., Kok, J. \& Venema, G. (1992). Gene expression in Lactococcus lactis. FEMS Microbiol Rev 88, 73-92.

Hanahan, D. (1983). Studies on transformation of Escherichia coli with plasmids. $J$ Mol Biol 166, 557-580.

Hellinga, H. W. \& Evans, P. R. (1985). Nucleotide sequence and high-level expression of the major Escherichia coli phosphofructokinase. Eur J Biochem 149, 363-373.

Knowles, J. R. (1991). Enzyme catalysis: not different, just better. Nature 350, 121-124.

Laemmli, U. K. (1970). Cleavage of structural proteins during assembly of the head of bacteriophage T4. Nature 227, 680-685.

Lipman, D. J. \& Pearson, W. R. (1985). Rapid and sensitive protein similarity searches. Science 227, 1435-1441.

Llanos, R. M., Hillier, A. J. \& Davidson, B. E. (1992). Cloning, nucleotide sequence, expression, and chromosomal location of $l d h$, the gene encoding $\mathrm{L}-(+)$-lactate dehydrogenase from Lactococcus lactis. J Bacteriol 174, 6956-6964.

Llanos, R. M., Harris, C. J., Hillier, A. J. \& Davidson, B. E. (1993). Identification of a novel operon in Lactococcus lactis encoding three enzymes for lactic acid synthesis: phosphofructokinase, pyruvate kinase, and lactate dehydrogenase. J Bacteriol 175, 2541-2551.

Lolis, E., Alber, T., Davenport, R. C., Rose, D., Hartman, F. C. \& Petsko, G. A. (1990). Structure of yeast triosephosphate isomerase at 1.9-A resolution. Biochemistry 29, 6609-6618.

Ludwig, W., Seewaldt, E., Kilpper-Balz, R., Schleifer, K. H., Magrum, L., Woese, C. R., Fox, G. E. \& Stackebrandt, E. (1985). The phylogenetic position of Streptococcus and Enterococcus. J Gen Microbiol 131, 543-551.

Miller, J. H. (1972). Experiments in Molecular Genetics. Cold Spring Harbor, NY: Cold Spring Harbor Laboratory.

Noltmann, E. A. (1972). Aldose-ketose isomerases. Triose-phos- phate isomerase. In The Enzymes, vol. VI, pp. 326-340. Edited by P. D. Boyer. London: Academic Press.

Pichersky, E., Gottlieb, L. D. \& Hess, J. F. (1984). Nucleotide sequence of the triose phosphate isomerase gene of Escherichia coli. Mol \& Gen Genet 195, 314-320.

Rentier-Delrue, F., Mande, S. C., Moyens, S., Terpstra, P., Mainfroid, V., Goraj, K., Lion, M., Hol, W. G. J. \& Marital, J. A. (1993a). Cloning and overexpression of the triosephosphate isomerase genes from psychrophilic and thermophilic bacteria. Structural comparison of the predicted protein sequences. $J \mathrm{Mol}$ Biol 229, 85-93.

Rentier-Delrue, F., Moyens, S., Lion, M. \& Marital, J. A. (1993b). Sequence of the triosephosphate isomerase-encoding gene isolated from the thermophile Bacillus stearothermopbilus. Gene 134, 137-138.

van Rooijen, R. J. \& de Vos, W. M. (1990). Molecular cloning transcriptional analysis, and nucleotide sequence of lac $R$, a gene encoding the repressor of the lactose phosphotransferase system of Lactococcus lactis. J Biol Chem 265, 18499-18503.

van Rooijen, R. J., van Schalkwijk, S. \& de Vos, W. M. (1991). Molecular cloning, characterization, and nucleotide sequence of the tagatose 6-phosphate pathway gene cluster of the lactose operon of Lactococcus lactis. J Biol Chem 266, 7176-7181.

van Rooijen, R. J., Gasson, M. J. \& de Vos, W. M. (1992). Characterization of the Lactococcus lactis lactose operon promoter: contribution of flanking sequences and LacR repressor to promoter activity. $J$ Bacteriol 174, 2273-2280.

Salama, M., Sandine, W. \& Giovannoni, S. (1991). Development and application of oligonucleotide probes for identification of Lactococcus lactis subsp. cremoris. Appl Environ Microbiol 57, 1313-1318.

Sambrook, J., Fritsch, E. F. \& Maniatis, T. (1989). Molecular Cloning: a Laboratory Manual, 2nd edn. Cold Spring Harbor, NY: Cold Spring Harbor Laboratory.

Schlapper, B. S. \& Zuber, H. (1992). Cloning and sequencing of the genes encoding glyceraldehyde-3-phosphate dehydrogenase, phosphoglycerate kinase and triosephosphate isomerase (gap operon) from mesophilic Bacillus megaterium: comparison with corresponding sequences from the thermophile Bacillus stearothermophilus. Gene 122, 53-62.

Schwinde, J. W., Thum-Schmitz, N., Eikmanns, B. J. \& Sahm, H.

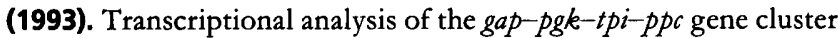
of Corynebacterium glutamicum. J Bacteriol 175, 3905-3908.

Sharp, P. M., Tuohy, T. M. F. \& Mosurski, K. R. (1986). Codon usage in yeast: cluster analysis clearly differentiates highly and lowly expressed genes. Nucleic Acids Res 14, 5125-5143.

Shimosaka, M., Fukuda, Y., Murata, K. \& Kimura, A. (1982). Application of hybrid plasmids carrying glycolysis genes to ATP production by Escherichia coli. J Bacteriol 152, 98-103.

Staden, R. (1978). Further procedures for sequence analysis by computer. Nucleic Acids Res 5, 1013-1016.

Tanskanen, E. I., Tulloch, D. L., Hillier, A. J. \& Davidson, B. E. (1990). Pulsed-field gel electrophoresis of SmaI digests of lactococcal genomic DNA, a novel method of strain identification. Appl Environ Microbiol 56, 3105-3111.

Terzaghi, B. E. \& Sandine, W. E. (1975). Improved medium for lactic streptococci and their bacteriophages. Appl Microbiol 29, 807-813.

Thompson, J. (1989). $N^{5}$-(L-1-carboxyethyl)-L-ornithine: NADP ${ }^{+}$ oxidoreductase from Streptococcus lactis. Purification and partial characterization. J Biol Chem 264, 9592-9601.

Thompson, J. \& Saier, M. H., Jr (1981). Regulation of methyl- $\beta$-Dthiogalactopyranoside-6-phosphate accumulation in Streptococcus 
lactis by exclusion and expulsion mechanisms. $J$ Bacteriol 146, 885-894.

Thompson, J., Nguyen, N. Y., Sackett, D. L. \& Donkersloot, J. A. (1991a). Transposon-encoded sucrose metabolism in Lactococcus lactis. Purification of sucrose-6-phosphate hydrolase and genetic linkage to $N^{5}$-(L-1-carboxyethyl)-L-ornithine synthase in strain $\mathrm{K} 1$. J Biol Chem 266, 14573-14579.

Thompson, J., Sackett, D. L. \& Donkersloot, J. A. (1991b). Purification and properties of fructokinase I from Lactococcus lactis. Localization of $s c r K$ on the sucrose-nisin transposon Tn5306. J Biol Chem 266, 22626-22633.

Tinoco, I., Jr, Borer, P. N., Dengler, B., Levine, M. D., Uhlenbech, O. C., Crothers, D. M. \& Gralla, J. (1973). Improved estimation of secondary structure in ribonucleic acids. Nature New Biol 246, 40-41.

Tulloch, D. L., Finch, L. R., Hillier, A. J. \& Davidson, B. E. (1991). Physical map of the chromosome of Lactococcus lactis subsp. lactis
DL11 and localization of six putative rRNA operons. $J$ Bacteriol 173, 2768-2775.

de Vos, W. M., Boerrigter, I., van Rooyen, R. J., Reiche, B. \& Hengstenberg, W. (1990). Characterization of the lactose-specific enzymes of the phosphotransferase system in Lactococcus lactis. J Biol Chem 265, 22554-22560.

Wierenga, R. K., Nobel, M. E. M. \& Davenport, R. C. (1992). Comparison of the refined crystal structures of liganded and unliganded chicken, yeast and trypanosomal triosephosphate isomerase. J Mol Biol 224, 1115-1126.

Yanisch-Perron, C., Vieira, J. \& Messing, J. (1985). Improved M13 phage cloning vectors and host strains : nucleotide sequences of the M13mp18 and pUC19 vectors. Gene 33, 103-119.

Received 15 July 1994; revised 22 September 1994; accepted 11 October 1994. 